\title{
Review on the Research of shaman Sacrifice in the Court of Qing Dynasty
}

\author{
Xin Cui \\ Research Center for the Development of Minority Education in Northwest China, Northwest Normal \\ University, Lanzhou Gansu, 730070, China
}

Keywords: Qing dynasty, Shaman sacrifice, Research review.

\begin{abstract}
In recent years, the precious academic value of shamanism has attracted widespread attention in the academia, many scholars, both at home and abroad, have conducted in-depth research on it and made a lot of achievements. The research works about the Manchu shamanism also keep emerging in an endless stream, which mainly studied the shamanism from the perspective of anthropology, ethnology and religion. Major achievements are as follows: research content and research field continue to expand, and theoretical approaches tend to be diverse. At present, however, research and concerns about the logic system, essential characteristics and concept recognition, angle of research view, as well as the scope are still insufficient, which need to be further strengthened and expanded.
\end{abstract}

\section{Introduction}

Shamanism has always been a mystery religion. There are many ethnic groups around the world that believe in shamanism, among which the Manchu in China has embraced shamanism since ancient times and has always attached great importance to the shaman sacrifice, which have been documented in many literature. A Manchuria Sacrifice Ritual was even compiled during the reign of Emperor Qianlong to specifically regulate and record the shaman sacrifice ritual in Qing dynasty palace. In addition, most of the court documents in the Qing Dynasty specially recorded the shaman sacrifice ceremony, which is enough to prove the important role of shaman in Manchu. Moreover, the Qing regime had existed for nearly 300 years, its national cohesion not only included the blood ties, but also bore religious ties that would affect their common psychological quality - the shamanism. The entire Manchu stuck together by the same religious belief - the shamanism, that is why the research on Manchu's shamanism is of great significance. Therefore, the study on the shaman sacrifice system in the the court of Qing dynasty is beneficial to explain the values rooted in the deep national mentality and cultural psychological structure, and will contribute a lot to learn the cultural form of the Qing Dynasty and the influence of the Qing royal family's psychological factors on ruling their political culture.

In recent years, the precious academic value of shamanism has attracted widespread attention in the academia, and many scholars, both at home and abroad, have conducted in-depth research on it and made a lot of achievements. The research works about Manchu's shamanism also keep emerging in an endless stream, which were mainly conducted from the angle of anthropology, ethnology and religion.

\section{Current research situation in foreign countries}

From the perspective of the developing process of the discipline, studies on shamanism has mainly undergone several stages. Early studies were focused on extensive field investigations and collection and collation of data, published articles and writings also mainly remained in the stage of morphological description and feature introduction, while theoretical insights were rare. After entering the twentieth century, scholars in various countries gradually tried to conduct theory construction of shamanism, invariably focused the initial discussions on the definition of all the 
concepts of shamanism, and carried out extensive discussions about many issues, such as the nature of the shaman and the geographical scope of shamanism. Many scholars in the world view shamanism from the perspective of world outlook, for example, Nihelatz, a polish scholar, wrote a book named the shamanism of Various Nationalities in Siberia, and its first chapter was "World Outlook of the shamanism”. Shirokogorov finished the Basic Examination of Tungus shamanism after his investigation and research conducted from 1915 to 1916. In terms of the Manchu shaman culture, Russian scholars enjoyed the particularly prominent research achievements, and their works were also numerous, which set a good model for our research and study.

From the beginning of the nineteenth century, scholars from different countries began to pay attention to the research on shamanism sacrifice, conducted site investigation, visited the living shaman, collected shaman's oracles, divine song, as well as and instruments used in sacrifice, they moved across Asia, North Asia, East Asia and Northeast Asia, achieving fruitful results. In contrast, study on the sub-sacrifice in the church of Chinese Manchu shaman was relatively rough. In the 1980s, sinologists and scholars of Manchu in Europe had a strong interest in the God words of shamanism worship, so they collected different versions of the God words and conducted comparison among them, after that, supplemented by anthropology, sociology and other knowledge, they studied the historical evolution of Manchu. A Italian sinologist named Giovani Staley compared the records about Nurhachi in some books, including Manchuria Memoir, Memoir of Founder Emperor Wu, Memoir Rehabilitation of Founder by Kangxi, Memoir Rehabilitation of Founder by Qian Long, and Founding Strategy of the Qing Dynasty, all in Chinese version and Manchu version, from the writing style we can see its evolution process from spoken language usage and random description to written description and standardized records, which occurred throughout the history when Manchu was absorbing Chinese traditional culture. In addition, and Giovani Staley also noted the evolution process of the Chinese version of word "Tangse" from "temple" to "Tangzi". Zhou Shaoming, who was from the Oriental Institute of the University of Cambridge, UK, was the editor-in-chief of Chinese Official Ceremony and Court Religious Ritual, and the eleventh chapter, Manchu Shamanism Ritual in Qing Palace, written by American scholar Nicola de Cosmo, made an incisive analysis on the role of shamanism in promoting the transformation of Manchu from clan to country and order maintenance after the establishment of the state.

\section{Domestic research status:}

Study on shaman sacrifice in Qing Palace:

Shaman Sacrifice in Qing Palace (Ji Lin Literature Press, 1993), written by Liu Housheng, and Mysterious Shaman Sacrifice in Qing Palace (Liao Ning people's press, 1995), written by Jiang Xiangshun, both these two books are a arrangement and analysis about the Manchuria Regius Ritual Worship Ceremony, which was issued during the reign of Emperor Qianlong.

In Qing dynasty, Guanzhong area, together with worship Gods and worship heavens in Tangzi, was an important part of Manchu shaman activities, which not only presented some features of imperial sacrificial rites, but also bore the general form of Manchu sacrifice. The officially compiled Manchuria Ceremony of Worship Gods and Heavens during the reign of emperor Qian Long took imperial sacrificial rite as the mode, thus becoming the fundamental norm of sacrifice ceremony for Manchu bannermen. And there appeared an apparent Chinesization sign in shaman sacrifice in the Qing dynasty: during sacrifice ceremony, the Buddha, Bodhisattva and Guandi that the Han nationality believed in were not only placed at the most important position, but also their memorial tablets were enshrined in various worships and received frequent worship. In addition, decrees and regulations of Qing's imperial sacrifice enjoyed extremely strong political nature, which could be considered as a Chinesization form of palace shamanism. (Du Jiayi: Recognize shamanism from Palace Sacrifice and Tangzi Sacrifice in the Qing Dynasty, Study on Manchu, $1^{\text {st }}$ issue, 1990); apart from the extreme reverence that Manchu showed to God, the ancestor God was also possessed of important status in shaman sacrifice. shaman is mainly the spokesman of God and ancestor God, in 
that sense, belief in shaman is the bond that brought clans and tribes together. And the shaman culture originally belonged to Manchu folk belief was not abandoned with the the establishment of Qing dynasty. On the contrary, as a means to realize the cohesion of Manchu's mentality, the shaman culture was respected and inherited. All people, from the palace, princes and ministers, to ordinary Manchu, abide by the former customs and worship heaven and God. The shaman sacrifice in Qing palace epitomized all folk beliefs in shaman and converted to court etiquette and ceremonial. (Tao Lifan: shaman Sacrifice in Qing Court, Study on Northwest Ethnic Groups, $2^{\text {nd }}$ issue, 1992); Manchu shamanism is not only the core and essence of Manchu culture, but also a long-standing part with the most strong penetrability in its national culture. The royal family of the Qing dynasty conquered the central plain from northeast, its established sacrificial ritual in Qing palace mainly stemmed from Han system, which only conducted heaven worship in Tangzi and God worship in Palace of Earthly Tranquility, so the original customs of Manchuria could be reserved. However, though the sacrificial ritual in Qing palace derived from shamanism, it was also different from shamanism, because it incorporated the Han culture and other cultural elements and absorbed sacrificial temple rites of the past dynasties, thus its system and content was more cumbersome and complex. (Guo Shuyun: Discussion and Analysis on Manchuria’s God Worship and Heaven Worship, Social Science Journal, $5^{\text {th }}$ issue, 1992); The ritual activities in Qing palace happened frequently, among them, God worship and heaven worship in Palace of Earthly Tranquility was essential to the court etiquette, which had a strong characteristic of shamanism, being an unique way of court sacrifice in the Qing Dynasty. Before the Qing's entrance to Shanhaiguan, Tangzi in Shen Yang city and Qing Ning Gong (Hall of Peace and Tranquility) in imperial palace were the first places in China to hold shamanism sacrifice ritual in Qing palace. In the middle of $17^{\text {th }}$ century, the Manchu emperor in Qing Dynasty held shamanism worship in the hall of peace and tranquility and courtyard, so as to offer sacrifice to ancestor and God, redeem a vow to a God, and pray for bliss. (Fu Lianzhong: God Worship and Heaven Worship in Palace of Earthly Tranquility, The Forbidden City, $2^{\text {nd }}$ issue, 2002); the God worship and heaven worship in palace of earthly tranquility was viewed by the Qing dynasty as a grand ceremony which would be held in every morning and evening, grandly held in the first day of the lunar month, held in auspicious day praying for happiness, and grandly held in vertical pole time in spring and autumn, which was hosted by female official who enjoyed a third-class salary. The etiquette system of worship was recorded in Manchuria Regius Ritual Worship Ceremony and Record of Laws and Systems of Qing Dynasty, and the things used for worship, including memorial tablet, tools, offerings, worship rites and time, were all included in the decrees and regulations system, which was done by institution of rite, a branch of imperial household department, and relevant personnel (Luan Ye: Relics of Manchu shamanism and the Earliest shamanism Sacrifice in Qing Palace, Studies on Manchu, $1^{\text {st }}$ issue, 2011); through the analysis of the shaman ceremony in Qing Palace, Zhang Yahui discussed the myth basis of the "Manchuria central concept" (Study on the shaman Sacrifice in Qing Palace and Myth, Study on the History of the Qing Dynasty, $4^{\text {th }}$ issue, 2011); and Qiu Yuanyuan discussed the Manchuria elements in the ceremony system of Qing dynasty and its influence from emperor Shun Zhi to emperor Qian Long’s reign period (Qiu Yuanyuan: The Making and Significance of Sacrifice Ceremony in Manchuria Palace Early in the Middle of Qing Dynasty, Review on the History of the Qing Dynasty, 2011).

Some articles, including Layout of Palace of Earthly Tranquility's Articles in Their Original Forms (the Palace Museum Journal, $2^{\text {nd }}$ issue, 1960) written by Zhu Jiaqian and the Rise and Fall and Evolution of Court shaman Worship in Qing Dynasty ( Discussion about the History of Qing Court, 1996) written by Zhou Ailian, discussed shamanism from the perspective of Qing dynasty's palace history and provided a lot of precious information. Moreover, there are articles talking about palace culture, such as Qing Palace and shaman Culture (the Palace Museum Journal, $2^{\text {nd }}$ issue, 1993) written by Yan Chongnian and Customs and Habits in Qing Palace( Wu Han Historical Data, $2^{\text {nd }}$ issue, 2007 ) written by $\mathrm{Pu}$ Jie, and the two articles above respectively made a brief elaboration about the 
relationship between worship in Qing palace and shamanism, as well as the relation between livelihood in Qing palace and shamanism.

\section{Research on the shamanism Music of Qing Court}

The Qing Manchu ritual activities were often held in the "Tangzi" and "Palace of Earthly Tranquility", and music is a special "language" used by reader of prayer (shaman) to communicate with God in shaman worship, which shows its self-evident importance. Liu Guiteng, by taking the sacrifice offered to heaven in Qing Court's Tangzi and the fiesta in honor of a deity held in Palace of Earthly Tranquility as the objects of study, explored the profound origin relationship between the court and the folk music of shaman dances. (Liu Guiteng: The Relict Manchu shaman Dances - Music Activities both in Offering Sacrifice to Heaven in Tangzi and in the Fiesta in Honor of a Deity Held in Palace of Earthly Tranquility, The second annual conference of the Chinese Minority Music Academic Seminar, 1986) and (Liu Guiteng: Music Activities in The Manchu shaman Dances in Qing Court, Chinese Music, third issue, 1989); In addition, Wan Yi and Huang Haitao also believe that court offerings to Gods is a continuation of the Manchu traditional folk ritual activities in the Qing palace, and their paper also conducted sound recording to record eighteen praying songs in Manchu language according to Mr. Aisin Gioro Yingsheng's personal song (Wan Yi, Huang Haitao: Worship Music of Palace of Earthly Tranquility in Qing Court, fourth section of Study of the Manchus, Beijing national publishing house, 1998). In the Qing Dynasty, the traditional sacrifice in the court was similar to the connotation of traditional sacrifice in history, which was divided into three grades, namely great worship, medium worship and group worship. At the same time, the sacrificial tradition of the Manchu rulers themselves - Tangzi worship, was kept. And the corresponding sacrifice music was also composed of Zhonghe Shao music (used in great worship and medium worship), happy music to celebrate God, as well as Tangzi worship music. Being Zhonghe Shao music, the instrument used in great worship and medium worship remained the same, while the number of instruments was different. In addition, the level of sacrificial object can be changed with the need of the ruling ideology, and the content of sacrificial music would also be changed (Wen Xiangui: Study on worship music in Qing Dynasty Palace, Academic Journal of Yunnan Arts University, first issue, 2004); and Qiu Yuanyuan, based on the research status of Qing palace music in General Music History and the monograph of Qing palace music, made a brief review on the study of Qing music since twentieth Century (Qiu Yuanyuan: A summary of the Research on Court Music in Qing Dynasty, Research Trends of Chinese History, fifth issue, 2005).

\section{Comparative study of the shaman worship in Qing palace before and after Qing's Entrance to Shanhaiguan}

There are some literature that conducted one-sided comparative study on palace culture and sacrifice culture before and after the Qing, including Manchu shamanism and its Social Influence before Qing's Entrance to Shanhaiguan (Songliao Journal, 3rd Issue, 1988) written by Zhou Changyuan, the shamanism before and after Manchu's Entrance to Shanhaiguan (Manchu Studies, Fourth Issue, 1994) written by Zhang Shuqing, the shaman sacrifice in Qing Palace and its historical evolution (Study on the history of the Qing Dynasty, first issue, 1994) written by Jiang Xiangshun, and Manchu Court Culture before Qing's Entrance to Shanhaiguan (Social Science Journal, sixth issue, 1995) co-written by Zhi Yunting and Wang Peihuan.

Reviewing the great achievements made in the study of the court shaman sacrifice in the Qing Dynasty, there are still shortcomings in the study: (1) Existing research results are mostly concentrated in the early period of the Qing Dynasty (mainly end with the Qian Long reign period), so the scope of study needs further development; (2) The domestic scholars didn't make full use of Qing archives, in this way, the research on court shaman sacrifice in the Qing Dynasty couldn't be 
carried out carefully and systematically, therefore, the use of archives of Qing Dynasty palace is a breakthrough in the future study on the court shaman sacrifice in the Qing Dynasty.

Meanwhile, under the current historical conditions, conducting research on the shaman sacrifice according to the Qing Dynasty literature and Qing Archives has the following theoretical and practical application value: (1) shamanism is a world cultural phenomenon, the relevant shaman rituals and the songs of God retain a large amount of ancient cultural information and folk cultural factors, moreover, many excellent national cultural heritages and literary heritages are retained in this ancient folk beliefs. As an important part of shamanism culture, Manchu shamanism can be seen as a breakthrough in the study of shaman culture, therefore, the study on the shaman ritual in the court of Qing Dynasty is able to protect and develop the shaman culture which is a unique intangible cultural heritage, thus making contributions to the research of minority culture in our country. (2) shamanism is a pristine natural religion, and the shaman worship in the court of Qing Dynasty, in particular, is more of a human culture "continent" that worth exploring and developing. Through a large number of archives and literature data, the comprehensive investigation and study on the shaman worship ritual in the court of Qing Dynasty is a reproduction of Manchuria culture and shaman culture. Based on the study, shaman ritual and all kinds of ancient cultural phenomena that shamanism bearing can be better preserved, which also played a positive role in the preservation and protection of the cultural heritages of our country.

\section{Acknowledgments}

This paper is one of the phased results of Study on the Role of Court shaman Worship in National Integration and Cultural Identity in the Early Qing Dynasty, a Youth Fund Project launched by humanities and social sciences institution of the Ministry of Education which is focused on the research on the west and the border areas. Project No.: 15XJC770002.

\section{References}

[1] Cao Jinqing. "Yellow River in China" Shanghai Literature and Art Publishing House, 2000 edition

[2] Kasper Shi Manfei: "Institutional Economics - social order and public economics" Commercial Press, 2002, pp. 110-137.Electronic Industry, Vol. 6 (2014) No 53, p.25-26 